Seribu

Bintang
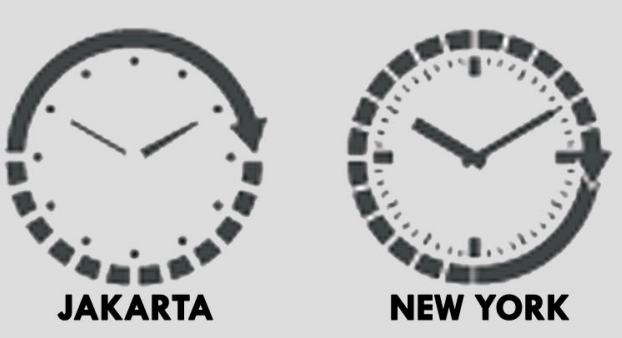

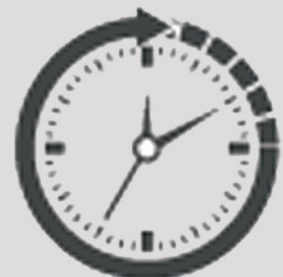

PYONGYANG

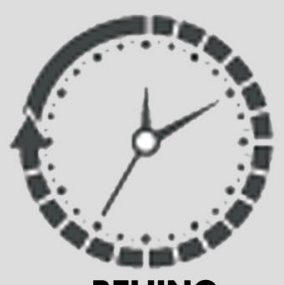

BEIJING
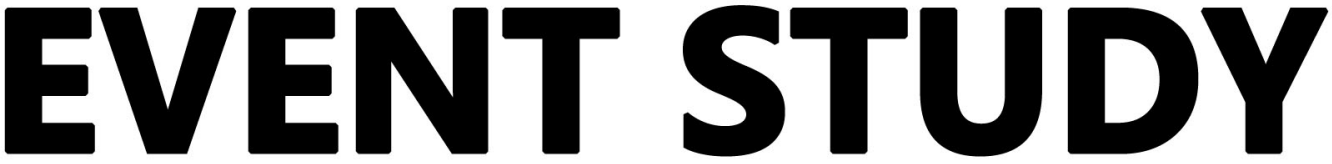

\title{
Teori
}

dan

Pembahasan

Reaksi Pasar Modal Indonesia

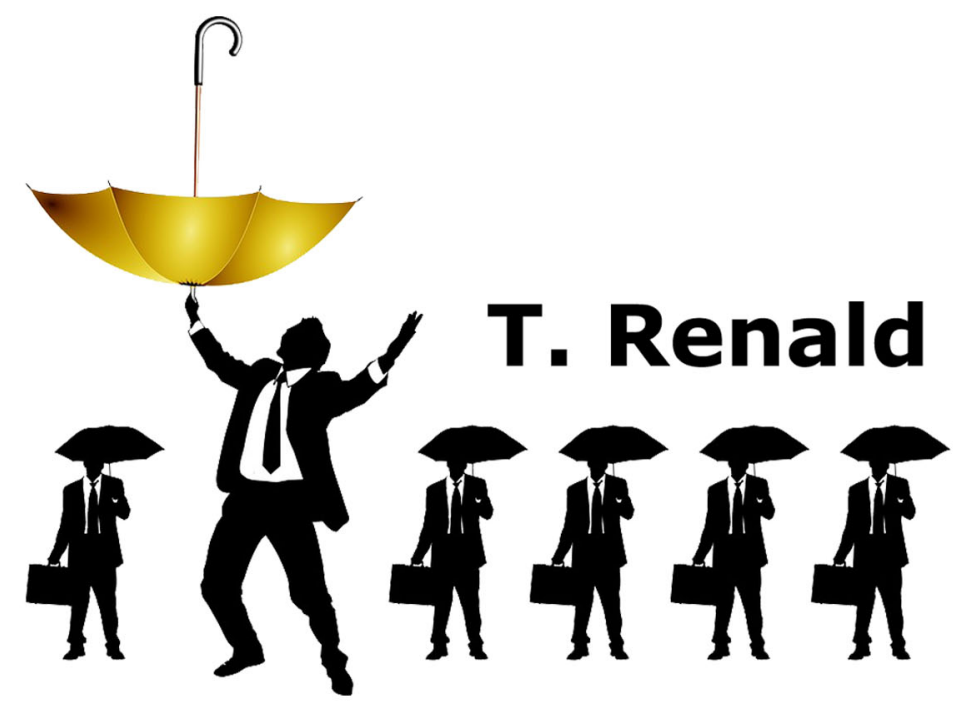




\section{Event Study \\ Teori dan Pembahasan Reaksi \\ Pasar Modal Indonesia}

\section{T. Renald Suganda}

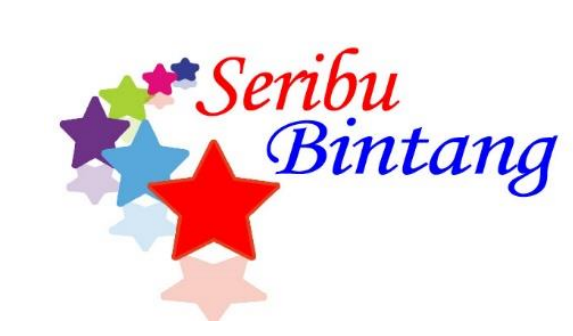




\section{Event Study \\ Teori dan Pembahasan Reaksi Pasar Modal Indonesia}

Penulis

Editor

Desain sampul
: T. Renald Suganda

: Soetam Rizky Wicaksono

: Tim Seribu Bintang

\section{Penerbit}

CV. Seribu Bintang

Malang - Jawa Timur - Indonesia

website: www.SeribuBintang.co.id

email : info@seribubintang.co.id

FB : www.fb.com/cv.seribu.bintang

ISBN : 978-602-52194-3-6

Edisi Pertama, Oktober 2018 Hak Cipta dilindungi oleh Undang-undang 


\section{Kontributor :}

Albert Christian

Audito Aji Anugrah

Christina Natalia Setiawan

Feni Sufuiana Thewelis

Gladys Miko Lukito

Miranti Verdiana Salim

Rendika Surya Herijanto

Sentoso Gosal

Wisda Milastri Sukrah HK Soba 


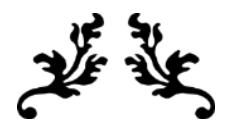

Opportunities come infrequently.

When it rains gold, put out the bucket, not the thimble 


\section{Kata Pengantar}

Puji syukur penulis panjatkan ke hadirat Tuhan YME karena atas berkat rahmat dan kuasaNya, buku Event Study: Teori dan Pembahasan Reaksi Pasar Modal Indonesia ini dapat terselesaikan.

Buku ini disusun sedemikian rupa berdasarkan latar belakang studi dan pengalaman penulis yang pernah mengenyam pendidikan pasca sarjana pada Program Studi Akuntansi, Fakultas Ekonomika dan Bisnis, di Universitas Gajah Mada, Yogyakarta, dengan berfokus pada bidang capital market based accounting research (riset akuntansi berbasis pasar modal). Saat ini, penulis aktif mengajar sebagai dosen pada Program Studi Akuntansi, Fakultas Ekonomi dan Bisnis di Universitas Ma Chung, Malang. Salah satu bidang kekhususan penulis baik dalam pengajaran, penelitian, maupun pengabdian pada masyarakat, adalah bidang investasi khususnya pasar modal. 
Buku ini menyajikan teori dan pembahasan reaksi pasar modal Indonesia terhadap beberapa contoh peristiwa yang dipilih oleh penulis berdasarkan pertimbangan tertentu pada tahun 2016-2018. Penekanan buku ini terletak pada teori dan pembahasan sederhana yang diharapkan dapat membantu para pembaca dalam mengidentifikasi reaksi pasar modal Indonesia terhadap suatu peristiwa. Peristiwa apa saja yang akan dianalisis, bagaimana mekanisma pengujian efisiensi pasarnya, serta apa indikator reaksi pasar dan bagaimana pengukurannya, akan dijelaskan sekilas oleh penulis di bagian Pendahuluan pada buku ini. Setelah bagian Pendahuluan, buku ini akan langsung menuntun para pembaca ke beberapa studi peristiwa yang dipilih untuk dibahas.

Siapa sajakah para pembaca yang dapat menggunakan buku ini? Pertama, buku ini ditujukan kepada mahasiswa strata satu (S1) program studi akuntansi maupun manajemen yang sedang melakukan penelitian pasar modal 
dengan metodologi event study (studi peristiwa). Buku ini dapat dijadikan sebagai bahan referensi, atau sebagai bahan bacaan pendukung untuk menambah wawasan keilmuan pasar modal, atau bahkan lebih lanjut sebagai dasar dalam rangka pengembangan penelitian. Kedua, buku ini ditujukan kepada para peneliti (baik pemula maupun senior) di bidang pasar modal sebagai dasar pengembangan penelitian maupun sebagai sarana hiburan intelektual.

Dalam proses penyusunan buku ini, tentunya penulis tidak menyelesaikannya dengan usaha seorang diri. Terdapat beberapa pihak sangat membantu dan memotivasi penulis dalam upaya penyelesaian buku ini. Untuk itu, penulis mengucapkan terima kasih kepada beberapa profesor di Universitas Gajah Mada, Yogyakarta, yang secara khusus telah memberikan dasar yang kuat dalam mengeksplorasi bidang ini. Ucapan terima kasih juga dihaturkan kepada keluarga, sahabat, rekan-rekan dosen, dan rekan sebidang ilmu yang selalu memberikan dorongan 
kepada penulis demi terselesaikannya buku ini. Tak lupa, penulis pun mengucapkan terima kasih kepada rekan tim mahasiswa terpilih yang telah berkontribusi dalam penyusunan buku ini.

Buku yang telah tersusun ini tentunya masih belum sempurna. Oleh karena itu, kritik dan saran dari para pembaca sangat dibutuhkan oleh penulis demi penyempurnaan buku ini nantinya.

Terima kasih dan mari bersama-sama berproses demi kemajuan keilmuan di bidang pasar modal.

Universitas Ma Chung, Malang Agustus 2018

Penulis Tarsisius Renald Suganda, S.E., M.Si 


\section{Daftar Isi}

Kontributor : ................................................. i

Kata Pengantar ........................................... ii

Daftar Isi.................................................. vii

Pendahuluan .................................................1

Reaksi Pasar Modal Indonesia terhadap

Peristiwa Peluncuran Rudal Korea Utara..... 7

Sekilas Peristiwa .................................... 8

Tinjauan Pustaka.................................. 13

Metoda Penelitian ............................... 19

Hasil dan Pembahasan ........................... 26

Daftar Pustaka .................................... 33

Dampak Reaksi Pengumuman Perang Dagang Amerika Serikat dan Republik Rakyat China terhadap Pasar Modal Indonesia

Sekilas Peristiwa ..................................... 36

Metoda Penelitian ................................. 46

Simpulan ........................................ 54

Daftar Pustaka ................................... 56

Abnormal Return dan Trading Volume Activity sebagai Bentuk Reaksi Pasar Modal terhadap Peristiwa Bom Sarinah ............... 59

Sekilas Peristiwa ...................................6 60

Tinjauan Pustaka ...................................... 65

Metoda Penelitian ................................ 72

Hasil dan Pembahasan ........................... 82 
Simpulan ........................................... 90

Daftar Pustaka ................................ 92

...................................................................994

Dampak Perubahan Harga Batu Bara Domestic Market Obligation terhadap Kinerja Saham Perusahaan Batu Bara .......95

Sekilas Peristiwa ................................... 96

Tinjauan Pustaka ................................. 101

Metoda Penelitian ............................... 108

Hasil dan Pembahasan ........................... 117

Simpulan ...................................... 127

Daftar Pustaka ................................ 129

Reaksi Pasar Saham Indonesia terhadap Pengumuman Kenaikan Suku Bunga The Federal..................................................... 131

Reserve Bank ...................................... 131

Sekilas Peristiwa ................................ 132

Tinjauan Pustaka............................... 136

Metoda Penelitian ............................... 147

Hasil dan Pembahasan .......................... 152

Simpulan ...................................... 160

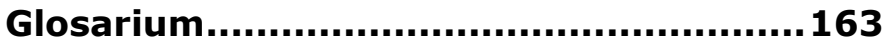






\section{Pendahuluan}

Studi peristiwa atau event study di bidang pasar modal merupakan suatu studi yang dilakukan secara empiris untuk menganalisis dampak terjadinya suatu peristiwa terhadap pasar modal suatu negara. Dengan kata lain, studi ini dilakukan untuk menginvestigasi reaksi pasar modal terhadap suatu peristiwa. Dalam penelitian pasar modal, khususnya pengujian efisiensi pasar, event study merupakan metodologi yang digunakan untuk menguji efisiensi pasar bentuk setengah kuat (semi strong form).

Buku ini disusun dengan membahas lima peristiwa yang berbeda pada perioda 2016 2018. Sebenarnya terdapat banyak sekali peristiwa yang dapat diteliti, namun penulis hanya mengambil lima contoh peristiwa saja untuk dibahas di dalam buku ini. Dari kelima peristiwa yang dipilih tersebut, tidak ada satupun jenis peristiwa konvensional yang diambil sebagai contoh. Reaksi pasar modal yang diinvestigasi adalah reaksi pasar modal di negara Indonesia. 
Buku ini membahas lima contoh peristiwa sebagai bahan kajian yaitu:

1. Bom Sarinah (2016)

2. Peluncuran Rudal Korea (2017)

3. Pengumuman Kenaikan Suku Bunga The Fed (2017)

4. Penurunan Harga Batu Bara DMO (2018)

5. Perang Dagang Amerika Serikat dan China (2018)

Secara empiris, pengujian umum terhadap respons atau reaksi pasar adalah menggunakan indikator abnormal return. Dalam buku ini, indikator reaksi pasar yang ditambahkan adalah trading volume activity. Data yang dibutuhkan dalam pengujian didapatkan dari Galeri Investasi Universitas Ma Chung sebagai unit yang dikelola Universitas Ma Chung atas hasil sinergi dengan Bursa Efek Indonesia dan Anggota Bursa yaitu Danareksa Sekuritas.

Buku ini disusun dengan membahas lima peristiwa yang berbeda pada perioda 2016 - 2018. 
Untuk menghitung nilai abnormal return, maka nilai actual return dan expected return harus didapatkan terlebih dahulu. Penulis membatasi hanya menggunakan satu model pengujian expected return yaitu market-adjusted model (dua model lainnya yang dapat digunakan oleh pembaca sebagai pengembangan penelitian adalah market model dan mean-adjusted model).

Market-adjusted model dapat digunakan tanpa membutuhkan perioda estimasi sehingga relatif lebih ringkas pengujiannya dan model ini memprediksi expected return berdasarkan return indeks pasar. Alat statistik yang digunakan untuk menjawab ada tidaknya abnormal return adalah One Sample t-test. Penulis berpendapat bahwa One Sample t-test dapat mendeteksi di hari ke berapakah reaksi pasar terjadi secara signifikan, bahkan pada hari $\mathrm{H}$ saat terjadinya peristiwa pun ( $\left.t_{0}\right)$ dapat terdeteksi apakah signifikan atau tidak reaksinya. Jadi, menurut penulis, pengujian abnormal return dalam peristiwa yang dibahas di buku ini bukan dengan cara membedakan ratarata abnormal return sebelum dan setelah peristiwa, namun lebih tepat digunakan untuk melihat pada hari ke berapa reaksi pasar modal 
ditemukan secara signifikan. Oleh karena itu, alat statistik yang digunakan adalah one sample t-test (bukan menggunakan paired sample t-test).

Untuk menghitung indikator kedua yaitu trading volume activity (TVA), data voluma perdagangan saham dan voluma saham beredar harus didapatkan terlebih dahulu. Untuk melihat ada tidaknya reaksi pasar yang signifikan, penulis menggunakan uji beda rata-rata TVA sebelum dan setelah peristiwa untuk melihat perbedaan voluma perdagangan.

Market-adjusted model dapat
digunakan tanpa membutuhkan
perioda estimasi sehingga relatif lebih
ringkas pengujiannya dan model ini
memprediksi expected return
berdasarkan return indeks pasar.

Penulis berpendapat bahwa uji beda ratarata TVA setelah dan TVA sebelum peristiwa adalah tepat jika menggunakan alat uji statistik Paired Sample t-test atau bahkan dapat juga menggunakan alat uji statistik Wilcoxon Signed Rank Test jika hasil uji normalitas datanya ternyata tidak terdistribusi secara normal. Jadi, dalam buku ini (berdasarkan lima contoh 
peristiwa yang dibahas), alat uji statistik yang digunakan untuk pengujian abnormal return adalah one sample t-test, namun untuk pengujian TVA adalah paired sample t-test.

Demikian beberapa informasi dan batasan yang digunakan penulis terkait proses penyusunan buku ini. Para pembaca diharapkan membaca bagian ini terlebih dahulu sebelum beralih ke konten buku lebih lanjut.

Semoga buku ini dapat bermanfaat bagi para pembaca. 


\section{造就}

Risk comes from not knowing what

you are doing 


\section{Reaksi Pasar Modal Indonesia terhadap Peristiwa Peluncuran Rudal Korea Utara}




\section{Sekilas Peristiwa}

Pada tanggal 29 Agustus 2017, Korea Utara menembakkan sebuah rudal dari dekat ibu kota Pyongyang yang melintasi wilayah udara Jepang dan jatuh di Samudra Pasifik di lepas pantai Pulau Hokaido. Rudal yang meluncur 2.700 $\mathrm{km}$ dan pada ketinggian maksimum $550 \mathrm{~km}$ tersebut merupakan serangkaian uji coba peluncuran rudal kedua yang dilakukan oleh pihak Korea Utara. Peristiwa tersebut merupakan tindakan ancaman balik yang dilontarkan oleh Korea Utara terhadap Amerika Serikat (AS).

Setelah peristiwa peluncuran rudal pertama, Korea Utara kembali mengancam akan meluncurkan rudal kedua di Guam, yang merupakan salah satu dari wilayah Amerika Serikat dan menjadi lokasi kedua pangkalan militer AS. Terdapat setidaknya 163.000 warga sipil di Guam dan sekitar 6 ribu personil militer AS yang ditugaskan di pulau ini (www.bbc.com, 2018). Dengan kondisi tersebut, ketegangan geopolitik antara Korea Utara dan Amerika Serikat akan semakin memuncak. Selain itu, ketegangan yang terjadi dapat berimbas pada melemahnya 
indeks negara-negara Asia maupun Amerika Serikat. Secara khusus di Indonesia, terjadi aksi jual yang cukup tinggi di Bursa Efek Indonesia (BEI) yang menyebabkan Indeks Harga Saham Gabungan (IHSG) pada perdagangan hari Selasa, 29 Agustus 2017 (tepat pada saat peluncuran rudal) mengalami penurunan sebesar $0,26 \%$ atau 15,129 poin ke level $5.888,212$ dari penutupan sebelumnya yaitu pada level 5.903,341 (www.market.bisnis.com, 2018).

\begin{tabular}{l}
\hline \hline Aksi jual cukup tinggi terjadi di Bursa \\
Efek Indonesia yang menyebabkan \\
Indeks Harga Saham Gabungan \\
(IHSG) pada perdagangan hari Selasa, \\
29 Agustus 2017 (tepat pada saat \\
peluncuran rudal) mengalami \\
penurunan sebesar 0,26\% atau 15,129 \\
poin ke level 5.888,212 dari \\
penutupan sebelumnya di level \\
$5.903,341$
\end{tabular}

Peristiwa tersebut diperkirakan dapat memberikan sinyal buruk atau bad news bagi pelaku pasar modal atau para investor. Hal ini disebabkan oleh menegangnya perseteruan kedua negara yang mampu membawa dampak ekonomi pada kedua negara tersebut dan juga negara lain 
yang memiliki ikatan ekonomi dan hubungan perdagangan dengan AS dan Korea Utara. Indonesia sebagai salah satu negara yang memiliki ikatan ekonomi dengan AS juga terdampak.

Data yang tercatat sampai pada 9 Maret 2018 menunjukkan bahwa komposisi kepemilikan efek oleh pihak asing adalah sebesar $44,45 \%$ atau setara dengan Rp2.026,52 triliun. Sedangkan kepemilikan efek oleh investor lokal adalah sebesar 55,55\% atau senilai Rp2.533,05 triliun (https://investasi.kontan.co.id, 2018). Akibatnya, dengan adanya peristiwa tersebut, dugaan bahwa para investor asing akan menarik dananya dari pasar modal Indonesia dan akan dialihkan pada investasi yang lebih aman juga semakin kuat.

Pasar modal dikatakan efisien apabila pasar mampu bereaksi dengan cepat dan akurat untuk mencapai harga keseimbangan baru yang sepenuhnya mencerminkan informasi yang tersedia (Hartono, 2017). Peristiwa yang mempengaruhi pasar modal pada prinsipnya mengandung suatu informasi. Kandungan informasi yang diserap oleh pasar akan digunakan para investor untuk menentukan keputusan 
investasinya, sehingga investor akan berupaya untuk mendapatkan informasi yang lengkap dan akurat. Kemampuan pasar yang efisien dalam menerima informasi yang terjadi dijelaskan pula dalam signaling theory. Teori ini menjelaskan bahwa sinyal-sinyal yang timbul dari informasi, baik yang berasal dari eksternal perusahaan (inflasi, kebijakan pemerintah, bencana alam, dan lainnya) maupun internal perusahaan (berupa corporate action, kebijakan manajemen lainnya) secara langsung akan berpengaruh terhadap pergerakan harga dari perusahaan terkait.

Pasar dikatakan efisien bila pasar mampu bereaksi cepat dan akurat untuk mencapai harga keseimbangan baru yang sepenuhnya mencerminkan informasi yang tersedia.

Peristiwa peluncuran rudal Korea Utara yang akhirnya menyebabkan ketegangan dengan Amerika Serikat dianggap sebagai bad signal bagi pasar modal Indonesia. Dalam investigasi efisiensi pasar modal, khususnya peristiwa peluncuran rudal ini, studi peristiwa atau event study adalah metoda yang tepat digunakan dalam pengujian. 
Menurut Tandelilin (2010), event study menggambarkan sebuah teknik riset keuangan empiris yang memungkinkan seorang pengamat menilai dampak dari suatu peristiwa terhadap harga saham perusahaan. Dalam kajian ini, tolok ukur yang digunakan untuk membuktikan adanya reaksi pasar modal adalah dengan melihat indikator abnormal return dan aktivitas voluma perdagangan saham (trading volume activity).

Berdasarkan isu yang ada, maka rumusan masalah dalam penelitian ini adalah: (1) Apakah terdapat reaksi pasar atas peristiwa peluncuran rudal Korea Utara yang tercermin dalam abnormal return yang signifikan? (2) Apakah terdapat reaksi pasar atas peristiwa peluncuran rudal Korea Utara yang tercermin dalam Trading Volume Activity (TVA)? 


\section{Tinjauan Pustaka}

\section{Hipotesis Pasar Efisien}

Pasar efisien adalah pasar tempat harga sekuritas sama dengan nilai investasi sepanjang waktu yang berarti bahwa setiap sekuritas dijual pada harga yang wajar setiap waktu. Pasar modal dikatakan efisien apabila pasar mampu bereaksi dengan cepat dan akurat untuk mencapai harga keseimbangan baru yang sepenuhnya mencerminkan seluruh informasi yang tersedia. Fama (1970) mengategorikan hipotesis pasar efisien menjadi tiga bentuk yakni pasar efisien lemah (weak form), pasar efisiensi setengah kuat (semi strong form), dan pasar efisiensi sangat kuat (strong form).

Tiga macam bentuk efisiensi pasar, antara lain: (1) pasar efisien bentuk lemah (weak form), yaitu pasar dikatakan efisien jika harga-harga dari sekuritas mencerminkan secara penuh (fully reflect) informasi masa lalu (seperti harga dan voluma perdagangan, serta peristiwa di masa lalu); (2) pasar efisien bentuk setengah kuat (semi strong form), yaitu pasar dikatakan efisien 
jika harga-harga sekuritas mencerminkan secara penuh semua informasi historis dan informasi yang dipublikasikan termasuk informasi yang berada di laporan keuangan. Informasi tersebut dapat berupa informasi yang berasal dari emiten yang hanya memengaruhi harga saham dari emiten tersebut, informasi yang memengaruhi harga saham beberapa sekuritas; dan (3) pasar efisien bentuk kuat (strong form), yaitu pasar dikatakan efisien jika harga-harga sekuritas secara penuh mencerminkan semua informasi yang tersedia termasuk informasi yang privat.

Pasar modal dikatakan efisien apabila pasar mampu bereaksi dengan cepat dan akurat untuk mencapai harga keseimbangan baru.

Tujuan Fama mengklasifikasikan pasar efisien menjadi tiga bentuk ini adalah untuk mempermudah penelitian-penelitian yang dilakukan terhadap efisiensi pasar (Tandelilin, 2010). Pada tahun 1991, Fama melakukan penyempurnaan atas klasifikasi efisiensi pasar tersebut. Efisiensi pasar bentuk lemah disempurnakan menjadi klasifikasi yang lebih 
bersifat umum untuk menguji return prediktabilitas (return predictability). Sedangkan pengujian efisiensi pasar bentuk setengah kuat digunakan untuk menguji studi peristiwa (event studies). Untuk pengujian efisiensi pasar dalam bentuk kuat, pengujiannya disebut sebagai pengujian informasi privat.

\section{Signaling Theory}

Menurut Brigham \& Houston (2011), signaling theory adalah tindakan yang diambil dari manajemen perusahaan untuk memberikan petunjuk bagi investor mengenai prospek perusahaan. Sedangkan menurut Scott (2012), sinyal adalah sebuah tindakan yang diambil oleh high type manager yang mana tidak akan rasional jika dilakukan oleh low type manager.

Berdasarkan pengertian tersebut, teori penyinyalan (signaling theory) merupakan teori yang digunakan untuk memahami suatu tindakan oleh pihak manajemen dalam menyampaikan informasi kepada investor yang pada akhirnya dapat mengubah keputusan investor dalam melihat kondisi perusahaan. Informasi yang simetris adalah kondisi ideal yang diharapkan 
para investor (disebut pihak prinsipal) ketika manajemen perusahaan (disebut pihak agen) memberikan informasinya. Namun, terkadang penyampaian informasi yang asimetris pun terjadi. Menurut Jensen \& Meckling (1976), informasi asimetris terjadi karena terdapat salah satu pihak yang selalu berupaya memaksimalkan utilitasnya. Alasan yang muncul seringkali adalah bahwa pihak agen memiliki informasi penuh dalam perusahaan dan tidak selalu bertindak yang terbaik untuk kepentingan pihak prinsipal. Informasi asimetris ini dapat mempengaruhi kondisi dan prospek perusahaan.

Teori penyinyalan (signaling theory) menjelaskan tindakan-tindakan pihak manajemen dalam menyampaikan informasi kepada investor yang pada akhirnya dapat mengubah keputusan investor. 


\section{Abnormal Return}

Abnormal Return merupakan kelebihan dari return yang sesungguhnya terjadi (realisasi) terhadap return normal (Hartono, 2017). Return normal merupakan return ekspektasian atau return yang diharapkan oleh investor. Dengan demikian return tidak normal adalah selisih antara return sesungguhnya yang terjadi dengan return ekspektasian. Return realisasi (actual return) dapat dikatakan juga sebagai return yang telah terjadi dan dihitung berdasarkan data historis. Return ekspektasian (expected return) merupakan return yang diharapkan akan diperoleh oleh investor di masa mendatang. Berbeda dengan return realisasi, return ekspektasi merupakan return yang belum terjadi.

\section{Trading Volume Activity (TVA)}

Trading Volume Activity (TVA) merupakan indikator yang digunakan untuk mengamati serta mengukur reaksi pasar modal terhadap informasi atau peristiwa yang terjadi di pasar modal. Informasi atau peristiwa tertentu dapat memicu pergerakan saham di pasar modal yang akan mempengaruhi penawaran dan permintaan 
saham. Trading volume activity (aktivitas voluma perdagangan) merupakan penjualan dari setiap transaksi yang terjadi di bursa saham pada saat waktu tertentu untuk saham tertentu, dan merupakan salah satu faktor yang juga memberikan pengaruh terhadap pergerakan saham.

Trading Volume Activity (TVA) merupakan suatu indikator yang dapat digunakan untuk melihat reaksi pasar modal terhadap informasi yang beredar di pasar modal dengan menggunakan aktivitas voluma perdagangan saham sebagai parameternya. Trading Volume Activity (TVA) sering digunakan sebagai alat untuk mengukur likuiditas saham. Apabila voluma saham yang diperdagangkan lebih besar daripada voluma saham yang diterbitkan, maka semakin likuid saham tersebut sehingga aktivitas voluma perdagangan meningkat. 


\section{Metoda Penelitian}

Sampel yang digunakan dalam penelitian ini adalah seluruh perusahaan yang termasuk ke dalam indeks LQ 45. Indeks LQ 45 dipilih karena indeks ini terdiri atas 45 perusahaan yang memiliki tingkat likuiditas, kapitalisasi pasar yang tinggi di BEI, serta merupakan indeks yang terdiri atas perusahaan yang paling aktif diperdagangkan. Sampel yang digunakan dalam penelitian ini harus memenuhi beberapa kriteria sebagai berikut.

1. Merupakan perusahaan yang termasuk ke dalam indeks LQ45 pada perioda penelitian.

2. Memiliki nilai harga penutupan saham (closing price).

3. Tidak mengalami suspend dan delisting pada perioda penelitian.

4. Tidak melakukan corporate action pada perioda penelitian.

Berdasarkan hasil kriteria tersebut, maka diperoleh sampel sebanyak 45 perusahaan yang akan digunakan dalam penelitian ini sebagai berikut. 


\section{Tabel 1. Sampel Penelitian}

\begin{tabular}{|c|c|c|}
\hline No. & $\begin{array}{c}\text { Kode } \\
\text { Saham }\end{array}$ & Keterangan \\
\hline 1 & AALI & Astra Agro Lestari Tbk \\
\hline 2 & ADHI & Adhi Karya (Persero)Tbk \\
\hline 3 & ADRO & Adaro Energy Tbk \\
\hline 4 & AKRA & AKR Corporindo Tbk \\
\hline 5 & ANTM & Aneka Tambang (Persero) Tbk \\
\hline 6 & ASII & Astra International Tbk \\
\hline 7 & BBCA & Bank Central Asia Tbk \\
\hline 8 & BBNI & $\begin{array}{l}\text { Bank Negara Indonesia (Persero) } \\
\text { Tbk }\end{array}$ \\
\hline 9 & BBRI & $\begin{array}{l}\text { Bank Rakyat Indonesia (Persero) } \\
\text { Tbk }\end{array}$ \\
\hline 10 & BBTN & $\begin{array}{l}\text { Bank Tabungan Negara (Persero) } \\
\text { Tbk }\end{array}$ \\
\hline 11 & BJBR & BPD Jawa Barat dan Banten Tbk \\
\hline 12 & BMRI & Bank Mandiri (Persero) Tbk \\
\hline 13 & BMTR & Global Mediacom Tbk \\
\hline 14 & BRPT & Barito Pacific Tbk \\
\hline 15 & BSDE & Bumi Serpong Damai Tbk \\
\hline 16 & BUMI & Bumi Resources Tbk \\
\hline 17 & EXCL & XL Axiata Tbk \\
\hline 18 & GGRM & Gudang Garam Tbk \\
\hline 19 & HMSP & H. M. Sampoerna Tbk \\
\hline 20 & ICBP & $\begin{array}{l}\text { Indofood CBP Sukses Makmur } \\
\text { Tbk }\end{array}$ \\
\hline 21 & INCO & Vale Indonesia Tbk \\
\hline 22 & INDF & Indofood Sukses Makmur Tbk \\
\hline 23 & INTP & Indocement Tunggal Prakasa Tbk \\
\hline
\end{tabular}




\begin{tabular}{|c|c|c|}
\hline No. & $\begin{array}{c}\text { Kode } \\
\text { Saham }\end{array}$ & Keterangan \\
\hline 24 & JSMR & Jasa Marga (Persero) Tbk \\
\hline 25 & KLBF & Kalbe Farma Tbk \\
\hline 26 & LPKR & Lippo Karawaci Tbk \\
\hline 27 & LPPF & Matahari Department Store Tbk \\
\hline 28 & LSIP & PP London Sumatra Tbk \\
\hline 29 & MNCN & Media Nusantara Citra Tbk \\
\hline 30 & MYRX & Hanson International Tbk \\
\hline 31 & PGAS & $\begin{array}{l}\text { Perusahaan Gas Negara (Per } \\
\text { sero) Tbk }\end{array}$ \\
\hline 32 & PPRO & PP Properti Tbk \\
\hline 33 & PTBA & $\begin{array}{l}\text { Tambang Batubara Bukit Asam } \\
\text { (Persero) Tbk }\end{array}$ \\
\hline 34 & PTPP & PP (Persero) Tbk \\
\hline 35 & PWON & Pakuwon Jati Tbk \\
\hline 36 & SCMA & Surya Citra Media Tbk \\
\hline 37 & SMGR & Semen Indonesia (Persero) Tbk \\
\hline 38 & SMRA & Summarecon Agung Tbk \\
\hline 39 & SRIL & Sri Rejeki Isman Tbk \\
\hline 40 & SSMS & Sawit Sumbermas Sarana Tbk \\
\hline 41 & TLKM & $\begin{array}{l}\text { Telekomunikasi Indonesia } \\
\text { (Persero) Tbk }\end{array}$ \\
\hline 42 & UNTR & United Tractors Tbk \\
\hline 43 & UNVR & Unilever IndonesiaTbk \\
\hline 44 & WIKA & Wijaya Karya (Persero) Tbk \\
\hline 45 & WSKT & Waskita Karya (Persero) Tbk \\
\hline
\end{tabular}

Sumber: Data diolah, 2018 
Jenis data yang digunakan dalam penelitian ini adalah data kuantitatif dan sumber datanya adalah sumber data sekunder. Data kuantitatif yang digunakan adalah data berupa harga saham harian saat penutupan (closing price), dan voluma perdagangan saham. Terkait dengan sumber data, data didapatkan dari Galeri Investasi Universitas Ma Chung (GI-UMC) yang merupakan suatu unit penyedia data pasar modal di Universitas Ma Chung yang berdiri atas kerja sama dengan Bursa Efek Indonesia dan anggota bursa yaitu Danareksa Sekuritas.

Metoda pengumpulan data yang dilakukan dalam penelitian ini adalah metoda dokumentasi yaitu mengutip atau mengambil secara langsung dari sumber data yang tersedia. Market adjusted model adalah model perhitungan expected return yang dipilih untuk digunakan dalam penelitian ini. Berdasarkan market adjusted model, perioda yang digunakan dalam penelitian ini adalah perioda jendela saja (windows period) dan tanpa menggunakan perioda estimasi (estimation period). Model ini memiliki ciri yaitu return sekuritas yang diestimasi adalah sama dengan return indeks pasar atau dalam hal ini IHSG. 
Perioda jendela yang digunakan adalah sebelas hari bursa, yaitu lima hari sebelum ( $\mathrm{t}_{-5}$ ) dan lima hari setelah $\left(t_{+5}\right)$, dan event date $\left(t_{0}\right)$ yang jatuh pada tanggal 29 Agustus 2017. Adapun penggunaan perioda jendela 11 hari yaitu untuk memperkecil terjadinya confounding effect atau terjadinya perubahan harga saham karena faktor lain di luar perisiwa yang diamati.

Metoda pengumpulan data dalam
penelitian ini yaitu menggunakan
metoda dokumentasi atau kutipan
langsung terhadap data sekunder.

Untuk melihat ada tidaknya reaksi pasar modal, maka indikator yang digunakan dalam penelitian ini adalah Abnormal Return (AR) dan Trading Volume Activity (TVA). Abnormal Return merupakan kelebihan dari return yang sesungguhnya terjadi terhadap return normal. Trading Volume Activity (TVA) merupakan rasio antara jumlah lembar saham yang diperdagangkan pada waktu tertentu terhadap jumlah saham yang beredar pada waktu tertentu (Tandelilin, 2010). Oleh sebab itu, terdapat 2 
Tarsisius Renald Suganda adalah seorang Dosen Tetap sejak tahun 2008 pada Program Studi

Akuntansi, Fakultas Ekonomi dan Bisnis, di Universitas Ma Chung, Malang. Renald (panggilan akrab penulis) adalah lulusan dari Program Studi Akuntansi, Magister Sains Universitas Gajah Mada, Yogyakarta pada tahun 2008 .

Berbekal keilmuan dan proses pendampingan dari beberapa profesor di bidang keuangan dan pasar modal, topik tesis yang dikembangkan penulis saat itu adalah pengujian terhadap capital market efficiency. Sebelum mengawali karirnya sebagai dosen, yaitu tepatnya saat menempuh kuliah, penulis sudah menjadi investor di pasar modal Indonesia.

Sejak mengawali karirnya sebagai dosen, dan juga berbekal pengalaman sebagai investor pasar modal, penulis secara khusus menekuni bidang keilmuan market based accounting research. Penulis juga seringkali menjadi narasumber untuk bidang kajian pasar modal, dan juga aktif menjadi pembina Kelompok Studi Pasar Modal yang kerap kali menuai torehan prestasi di skala regional maupun nasional. Untuk konsultasi dan diskusi, penulis dapat dihubungi melalui alamat surel: renald.suganda@gmail.com

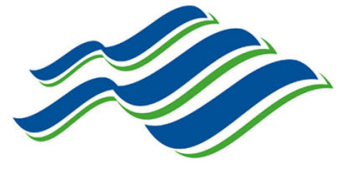

UNIVERSITAS MA CHUNG

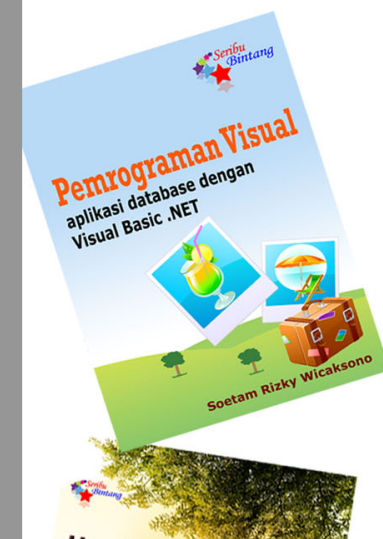

Hands On Lab:
SQL

Fundamental

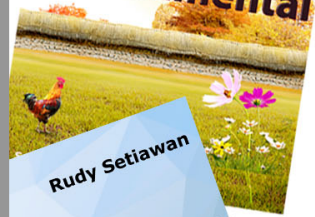



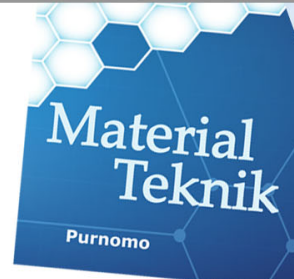

www.SeribuBintang.co.id

@ info@SeribuBintang.co.id

f fb.com/cv.seribu.bintang



